\title{
O SISTEMA DE RELAÇÕES DE TRABALHO NO BRASIL: alguns traços históricos e sua precarização atual
}

\section{Márcia da Silva Costa}

\section{Introdução}

As mudanças estruturais na economia brasileira no início dos anos de 1990, em especial, a abertura comercial promovida pelo governo Collor e ampliada pelo governo Cardoso, tomaram em cheio o setor industrial, rompendo com a política de substituição de importações, sustentáculo dos programas de desenvolvimento do país desde os anos de 1930. Esta experiência de adaptação competitiva ao mercado global deu início a processos generalizados de reestruturação produtiva dentro das empresas, lugar onde aquelas mudanças se concretizaram. Fechamento de fábricas, enxugamento de plantas, redução de hierarquias, concentração da produção nas áreas ou produtos de maior retorno, terceirização, modernização

Artigo recebido em setembro/2003

Aprovado em maio/2005 tecnológica, redefinição organizacional dos processos produtivos, entre outros, sintetizaram as estratégias empresariais, como estratégia mesmo de sobrevivência, resultando num fenômeno de demissão em massa de dimensão jamais vivida na história da industrialização do país.

Duas mudanças políticas interdependentes acompanharam essas transformações, notadamente no que se refere ao funcionamento do mercado de trabalho: a flexibilização dos regimes de trabalho (jornadas, salários, mobilidade funcional, ritmos) e a flexibilização/desregulamentação do sistema legislativo nacional de proteção ao trabalho, da CLT. Medidas provisórias como as que regularizavam o banco de horas, o contrato de trabalho por tempo determinado, a suspensão temporária do contrato de trabalho por motivos econômicos acenavam com a legitimidade institucional para a concretização daquela flexibilização, abrindo caminho para iniciativas de reformas 
pontuais importantes naquele ordenamento jurídico do trabalho. No presente texto procuro brevemente caracterizar as bases históricas, institucionais e políticas do sistema de relações de trabalho no Brasil como ferramenta analítica para a compreensão do impacto das transformações correntes na correlação de forças que imprime mudanças àquelas relações de trabalho e sua legislação. As propostas de flexibilização dos contratos de trabalho estão vindo à reboque das atuais estratégias de competitividade das empresas, mas em que sentido e respondendo a quais interesses? Quais as características da estrutura e do arcabouço institucional que regularam as relações de trabalho no Brasil no período áureo de consolidação de sua economia? Que transformações centrais elas sofreram em face das pressões dos movimentos de trabalhadores na luta por melhores condições de trabalho, de renda e de participação na definição política de seus interesses? Que outras transformações esse ordenamento legal do trabalho vem sofrendo ante a "inevitabilidade" de sua adequação às exigências atuais da acumulação capitalista? Existiu entre nós algum arranjo social que, grosso modo, pudesse ser equiparado ao pacto social fordista dos países centrais e que nos autorize a falar de seu desmonte? É o que pretendo aqui abordar. Em pauta: a institucionalização do modelo de representação sindical e as leis de proteção ao trabalho no governo Vargas; a repressão política e a flexibilização institucional desse sistema, impostas pelo regime militar; a revitalização do movimento sindical e as pressões pela redemocraticação do país animadas pelo novo sindicalismo; e, finalmente, o processo mais recente de retração desses movimentos, assolados pelo neoliberalismo e pela reestruturação produtiva nas empresas, e cuja luta política se direciona no sentido da desregulamentação daquele sistema de proteção trabalhista. O levantamento bibliográfico aqui realizado evidencia uma realidade histórica já conhecida, mas que prevalece e se amplia: o fato de que as relações de trabalho no país foram construídas sob condições de forte autoritarismo gerencial, e seu corolário, de debilidade da organização sindical. Isso permitiu a sedimentação de práticas associadas ao uso flexível e pre- cário do trabalho. A tendência recente de flexibilização da CLT agrava este quadro, põe em risco a garantia de direitos, investe na possibilidade de seu rebaixamento. Embora sejam grandes as necessidades de reforma, especialmente no que se refere à institucionalização de regras que assegurem a representação coletiva nos locais de trabalho e a negociação mais centralizada, a CLT ainda é o parâmetro central que impede que as relações de trabalho no país resvalem na pura mercantilização da força de trabalho.

\section{Representação sindical controlada e autoritarismo gerencial}

O sistema de regulação do trabalho no Brasil é um capítulo central na própria história das instituições políticas do país. Seu nascedouro acompanha as correntes ideológicas, as disputas e as lutas políticas e policiais, e a atividade legislativa que puseram em debate os preceitos do liberalismo econômico e da intervenção estatal desde final do século XIX até início dos anos de 1930, quando Vargas assume o comando do Estado. A política de substituição de importações, planejada e implementada sob a égide de um Estado forte e centralizador, fez incorporar, especialmente depois de 1945 , o padrão produtivo e tecnológico dominante nos países mais industrializados, facilitando a acumulação capitalista no país pelo controle e a integração limitada da classe operária. ${ }^{1}$

Controlando a ação direta dos sindicatos em troca de uma legislação minimamente protetora do trabalho, o Estado preparava as bases para a expansão acelerada do capitalismo no país. A ordem liberal estabelecida na Constituição de 1891 é rompida em 1926 com a emenda constitucional que põe termo ao preceito da liberdade das profissões e das atividades industriais, e entre 1931 e 1934 uma série de decretos passava a regulamentar a exploração do trabalho, ampliando a intervenção do Estado no mercado de trabalho. Essa intervenção, todavia, encarnava desde o princípio o espírito tutelador. Embora a Constituição de 1934 assegurasse a autonomia e a pluralidade sindicais, o Estado restringia a atuação dos sindicatos não apenas pelo fato de que cabia a ele o reconhecimento das 
associações, mas também pela natureza de sua articulação política com as lideranças sindicais. Ainda que não fosse completa sua interferência na organização dos estatutos, na definição dos processos eletivos, no controle administrativo e financeiro, no controle político e ideológico, como o que iria acontecer quando Vargas fecha o Congresso, o Estado cerceava aos poucos o livre movimento dos sindicatos, trazendo seus líderes para os quadros burocráticos, legislativos e judiciários, controlando-os, cooptando-os (Moraes Filho, 1978).

Com o golpe de 37, rompe-se de vez com a liberdade sindical, ordem que será central no regulamento corporativista inspirado na Carta del Lavoro do regime facista italiano. Assim, o decreto-lei de 1939 estabelece que os sindicatos só teriam poder de representação se fossem reconhecidos pelo Estado, cabendo a este o completo controle administrativo e político de suas atividades. A contrapartida, e o que provavelmente fez com que os trabalhadores aceitassem o reconhecimento de suas organizações sob o jugo do controle estatal, veio pela imposição legal às empresas de reivindicações trabalhistas elementares, objeto de décadas de lutas, direitos estes que se estenderam apenas às parcelas de trabalhadores urbanos representados pelos sindicatos legalmente reconhecidos. A grande massa de trabalhadores rurais, na época absoluta maioria da força de trabalho no país, permaneceu submetida ao livre poder de seus feitores e patrões, sem a cobertura dos direitos legais, por praticamente mais duas décadas.

A CLT brasileira - a cartilha dos direitos do trabalhador e seu certificado de cidadania ${ }^{2}-$, nasce, pois, com esse viés seletivo. Ela consolidava um conjunto de leis arbitrando o uso do trabalho na indústria nascente e restringindo a liberdade de contratação das empresas: limitação da jornada de trabalho em 48 horas, proibição do trabalho de menores de 14 anos, regulamentação do trabalho feminino, remuneração obrigatória da hora extra, descanso e férias remuneradas, condições de salubridade e proteção contra acidentes de trabalho, elevada indenização por dispensa imotivada, o que regulava a estabilidade no emprego para indivíduos com mais de dez anos de trabalho, entre outros. Por tal estatuto, o Estado delimitava o poder de atuação dos sindicatos e transferia para a esfera da Justiça do Trabalho a regulação dos conflitos trabalhistas. Em outras palavras, em sua estrutura original, o sistema de relações de trabalho no Brasil foi estabelecido com a intenção de que os sindicatos fossem vertidos em órgãos de colaboração com o Estado e na promoção da paz social. Como moeda de troca da redução dos direitos políticos e da liberdade de organização e reivindicação, a CLT assegurava vantagens trabalhistas e sociais mínimas por intermédio de uma política populista de incorporação estratégica e limitada da massa de trabalhadores (Rodrigues, 1968; Vianna, 1999; Rodrigues, 1974; Keck, 1988).

Sob esse modelo de corporativismo estatal, ${ }^{3}$ o nosso projeto de desenvolvimento realiza-se assentado numa base muito estreita e dependente de representação organizada dos trabalhadores ante as estruturas do Estado. Não vingou entre nós a noção de concertação política, baseada na negociação autônoma de interesses entre grupos organizados, tal qual a que aconteceu nos países desenvolvidos, que entendiam os contratos coletivos de trabalho como importante instrumento político-institucional. Longe de ser apoiado por qualquer espécie de arranjo social negociado entre as partes em conflito, nosso sistema de representação sindical nasce fortemente tutelado pelo Estado. Em seus traços gerais, ele foi constituído sob alguns condicionantes básicos que apenas menciono como forma de destacar os mecanismos do controle estatal: ${ }^{4}$

1. O enquadramento sindical dava-se (e ainda é assim) por categoria profissional ou setor econômico numa mesma base territorial, tendo como referência geográfica mínima o município.

2. A lei permitia a criação de uma estrutura verticalizada, composta de federações (a congregação de pelo menos dois sindicatos municipais de mesmo ramo) e de confederações (que reúnem as federações estaduais também de mesmo ramo). Limitando a representação por categoria profissional ou setor econômico num mesmo município e impedindo a representação congregada de diversas categorias, a legislação estabelecia (e ainda vige o mesmo princípio) o monopólio da representação. A organização intercategorias (centrais sindicais) era até a Constituição de 1988 proibida, mas se hoje tem forte papel político e de orientação ideo- 
lógica e prática sobre os sindicatos, não tem, no entanto, poder de contratação. Esta estrutura verticalizada e descentralizada foi responsável pela extrema fragmentação da representação sindical, facilitando ao Estado o controle das instituições e enfraquecendo o poder de pressão dos trabalhadores, que podiam estar divididos até mesmo no interior de uma mesma empresa.

3. O Estado também assegura a sobrevivência financeira dos sindicatos instituindo o imposto sindical anual, compulsoriamente extraído de um dia de trabalho de todos os trabalhadores, filiados ou não. Tal imposto, hoje chamado de contribuição sindical, juntamente com o princípio da unicidade (que garante o monopólio da representação), permitia que os sindicatos existissem independentemente da vontade de filiação ou da necessidade de mobilização dos trabalhadores, o que reforçava sua dependência em relação ao Estado. Essa característica é importante, como destaca Cardoso (1999), porque a receita decorrente da associação voluntária não estava relacionada com a sustentação financeira das práticas de mobilização dos sindicatos, e sim com sua burocracia assistencial. Isso limitava não apenas as possibilidades de filiação, e mesmo, o interesse nela, mas também o poder de pressão e reivindicação do sindicato, posto que desestimulava as ações de mobilização e aproximação entre as lideranças e as bases.

Ao dissociar a sobrevivência financeira dos sindicatos de sua capacidade de arregimentação, o Estado poderia cooptar as lideranças sindicais cuja atuação se pautasse não necessariamente pelos interesses imediatos dos trabalhadores que representavam, mas na capacidade de controle das manifestações voluntárias que ameaçassem a ordem social. Este foi o contexto que fez florescer as chamadas diretorias sindicais pelegas, que possuíam o poder de representação legal dos trabalhadores, mas, submissas ao Estado, não possuíam legitimidade representativa perante suas bases.

4. O sindicato só adquiria personalidade jurídica ou era legalmente reconhecido perante o Estado (Justiça do Trabalho) e o patronato, e, portanto, só poderia pleitear direitos, se obtivesse autorização do Ministério do Trabalho. Tal mecanismo permitia o controle administrativo e político sobre as atividades do sindicato, poder este exercido em sua autoridade absoluta ou de forma mais fle- xível, conforme a correlação de forças em cada conjuntura política/econômica. Foi assim que durante o autoritarismo do Estado Novo, com Vargas, e no período do regime militar, o Ministério do Trabalho fez chegar à minúcia a definição dos estatutos e a fiscalização sobre as ações administrativas e políticas dos sindicatos. Sob qualquer ameaça de perda de controle, sua intervenção poderia ser direta, afastando diretorias eleitas, perseguindo política e repressivamente os líderes e operários mais militantes. ${ }^{5}$

5. Os conflitos admitidos eram aqueles que resultavam de transgressão das garantias legais estabelecidas na CLT, e sua solução ocorria normalmente pela mediação da Justiça do Trabalho, seja pela via da indução do comum acordo entre as partes, seja pela via da arbitragem normativa. Assim, abriase um leque enorme para práticas despóticas de relações de trabalho por parte das gerências, cuja resistência e questionamento permaneciam latentes ou reprimidos no interior das empresas, sem a possibilidade legal de se manifestarem sob a forma de reivindicações coletivas organizadas e imediatas. Os conflitos eram, então, transferidos para a Justiça do Trabalho, desestimulando ou inibindo as oportunidades de confronto e tratamento direto das questões trabalhistas entre entidades sindicais operárias e patronais. Ademais, o controle estatal da política salarial dificultava ou tornava inócuas as iniciativas de negociação direta, tirando dos sindicatos um de seus espaços mais importantes de luta e representação. ${ }^{6}$

Em todos os aspectos da gestão interna do trabalho, a resolução dos conflitos que ficavam fora do que regulava a legislação permanecia prerrogativa do poder discricionário e unilateral dos patrões, reforçada ainda pelo fato de que a legislação não assegurava nenhuma forma de organização ou representação coletiva no interior das empresas. Esse aspecto é interessante ressaltar porque está na base do desenvolvimento no Brasil de uma cultura gerencial autocrática e paternalista que sempre relegou espaços de participação democrática no processo de trabalho e nas relações de produção.

6. As greves eram, senão estritamente proibidas, tremendamente dificultadas pelos procedimentos burocráticos exigidos para sua legalização, limitações legais que instrumentaram a ação militar repressiva e violenta por parte dos governos autoritários. 
Saídos deste arcabouço institucional, os sindicatos foram reconhecidos não para defender os interesses efetivamente demandados pelos trabalhadores ou barganhar diretamente soluções para os conflitos inerentes às relações de trabalho, mas para submeter aqueles conflitos ao controle do Estado. A proibição das greves e a ação repressiva sobre as manifestações populares e operárias limitaram o poder de pressão política dos trabalhadores e sua capacidade de questionar o autoritarismo das relações de trabalho no interior da produção. A validação do novo regime, no entanto, exigia reiteradamente a ação reivindicativa e contestatária dos trabalhadores. O conservadorismo empresarial, que fazia perpetuar práticas autoritárias de relações sociais e de trabalho, contribuiu para deixar no papel, para muitas categorias e por muitos anos, as conquistas da CLT. A massificação do assalariamento e dos direitos a ele pertinentes só veio acontecer entre o final dos anos de 1950 e início da década seguinte, quando a economia se dinamiza com a produção e o emprego gerado pela indústria de base, de bens de consumo duráveis e de bens de capital, com forte presença da atividade produtiva estatal e do capital multinacional.

Ainda assim, a política de substituição de importações não viria atrelada a uma política social ampla encarregada de redistribuir seus frutos por toda sociedade. É também a partir daquele período que a natureza autoritária e excludente do sistema de relações de trabalho se revela mais contraditória e incongruente com as demandas dos trabalhadores e suas condições de vida e trabalho. O crescimento econômico realizava-se sem uma associação direta com o aumento do padrão de renda/consumo e bem-estar da população e sem qualquer compromisso mais sólido com uma política de pleno emprego (pautada na estabilidade). Ao contrário, um certo desemprego estrutural era benéfico ao tipo de acumulação escolhido. Como destaca Mattoso, no Brasil, "ao contrário do que ocorreu nos países europeus, o padrão de produção baseado no setor de bens de consumo duráveis consolidou-se com baixos salários, elevada dispersão e sem distribuição de renda" (1996, p. 130). O que se constituía, então, era um padrão de desenvolvimento já extremamente seletivo.

Em face do privilégio estatal da expansão econômica nos grandes centros urbanos desenvol- via-se, paralelamente, toda uma rede informal de trabalho em pequenas empresas urbanas de fundo de quintal, no campo, e nas inúmeras formas de trabalho autônomo e precário, cujos padrões de contratação e assalariamento passavam ao largo da legislação trabalhista ou de qualquer forma de representação coletiva, e a quem eram relegados direitos mínimos de proteção social. A inexistência de um sistema amplo de regulação coletiva que tivesse por base a garantia de direitos cidadãos fez ampliar a heterogeneidade estrutural das condições de trabalho e emprego, restringindo o poder de abrangência da legislação trabalhista e social e criando um modelo dual de estabilidade (formalidade)/marginalidade para a economia e para o mercado de trabalho (Dombois e Pries, 2000). Além de fraca, a intervenção do Estado na criação de políticas e mecanismos de proteção social atingia apenas os trabalhadores formalmente reconhecidos pela relação salarial, possuidores de uma carteira de trabalho. Um tipo de incorporação social a que Santos chamou de cidadania regulada (ver nota 2). Essa base institucional alimentou todo um conjunto de valores na sociedade brasileira que associava tudo o que não constituísse trabalho formal (desemprego, formas de trabalho precário e instável) à marginalidade.?

No interior das empresas, por seu turno, predominavam as formas predatórias, pessoais e autoritárias de gestão do trabalho. A despeito dos ganhos em produtividade, as metas desenvolvimentistas e o crescimento econômico continuariam se dando à custa do desenvolvimento social e da concentração da riqueza, o que fez fomentar fortes ondas de contestação tanto nas fábricas quanto nos meios rurais. As reivindicações de cumprimento de direitos trabalhistas e de maior humanização das condições de trabalho, o arrocho salarial, a contestação da distribuição latifundiária traziam à tona os movimentos revolucionários que postulavam efetivas mudanças estruturais. As manifestações operárias e a efervescência dos movimentos populares alastraram-se, conquistando algum poder para pressionar o governo, como o espaço encontrado para as campanhas pelas reformas de base, e abrindo caminho para a reação conservadora e autoritária das classes dominantes. 


\section{Repressão militar e recrudescimento do regime autoritário de relações de trabalho}

O caminho da contenção dos movimentos operários e populares ocorreu, mais uma vez, pela via ditatorial, com o agravante da intervenção de um Estado que se impunha ideologicamente a legitimar em nome de uma ordem de segurança nacional, usando, para isso, da violência policial em dimensões e intensidade sem precedentes na história do país. O regime de governo pós-1964 cassou partidos políticos de esquerda, interveio direta e extensivamente nos sindicatos combativos, perseguiu, baniu, torturou ou assassinou seus líderes e operários mais militantes. Os movimentos sociais e as greves foram violentamente reprimidos e a intervenção estatal fez restringir a ação sindical às atividades burocráticas e assistencialistas. O peleguismo ${ }^{8}$ e a repressão praticamente anularam a representação sindical, sobretudo quando da imposição da política salarial pelo governo a partir de 1965, destituindo qualquer poder de negociação coletiva direta.

Nesse período pouco se precisou alterar no sistema de representação sindical para manter sob rígido controle a classe trabalhadora. Foi necessário apenas seguir à risca os dispositivos que restringiam o âmbito da atuação dos sindicatos e proibir, com rigor, as greves e as manifestações políticas. Uma das inovações na legislação trabalhista, no entanto, que veio ainda mais facilitar a exploração capitalista via uso predatório da força de trabalho, foi a instituição do FGTS, um mecanismo que ampliava o poder de demissão das empresas e que, aliado às práticas autoritárias e repressivas de gestão e à proibição das greves, fortalecia o grau de submissão dos trabalhadores.

O FGTS rompia com a lei da estabilidade no emprego para os trabalhadores com mais de dez anos de casa, uma garantia que, se não se consubstanciava na prática, pois as empresas muitas vezes demitiam seus empregados antes de completarem dez anos no emprego, alimentava ideologicamente uma noção de cooperação de classe fundada no direito do trabalho (Noronha, 1998; Humphrey, 1982). A lei do FGTS respondia, pois, às pressões das empresas por maior liberdade de demissão, economicamente justificada pela necessidade de serem realizados ajustes na folha de pagamento em conformidade com as oscilações na demanda. A diluição no tempo dos custos indenizatórios, permitida pelo novo sistema, significava a redução drástica do impacto financeiro direto das demissões, num momento em que a organização produtiva do processo de trabalho já se havia desenvolvido o suficiente para gerar um suprimento garantido de força de trabalho de baixa qualificação, o que estimulou a prática da alta rotatividade nas empresas. ${ }^{9}$

Em outras palavras, o sistema brasileiro de relações de trabalho vertia-se desde cedo e muito antes de as empresas virem seus lucros ameaçados pelos desafios internacionais da competitividade, num sistema altamente flexível e amplamente propenso a fomentar relações de trabalho hostis e precárias. Como conseqüência, à medida que a simplificação das tarefas tornava os trabalhadores substituíveis, estimulava-se a formação de um mercado de trabalho de pequena qualificação e de baixos salários. A alta rotatividade passaria a ser usada como uma prática recorrente das empresas não apenas como uma estratégia que permitia a manutenção de baixos salários, como constatou Humphrey (1982) em seu estudo de caso nas montadoras, mas também como um instrumento de controle disciplinar sobre a força de trabalho. Paralelamente, o controle oficial dos salários por meio de fórmulas que definiam reajustes abaixo da inflação real imputava aos trabalhadores os custos do crescimento, ao mesmo tempo em que estimulava as diferenciações salariais como estratégia de controle e distinção hierárquica dentro das empresas.

Como já dito, para conter a ação coletiva dos trabalhadores os militares valeram-se dos mecanismos de controle e repressão encontrados na própria legislação. Mas a principal característica da estrutura sindical que se consolida na era Vargas e que chega ao paroxismo nos governos militares foi que o Estado, por intermédio da Justiça do Trabalho, erigiu-se como instância normativa hegemônica na regulação dos conflitos entre capital e trabalho, arbitrando, inclusive, as negociações salariais. Ao se constituírem legalmente de forma descentralizada e longe dos locais de trabalho, os sindicatos, sem poder de pressão, tiveram ainda mais delimita- 
das sua esfera de atuação e suas demandas, o que, ao lado de um ambiente político repressivo e de um padrão despótico de gestão do trabalho, fez esvaziar o conflito dentro das fábricas, transferido-o para as esferas normativas da Justiça do Trabalho. No entanto, contrariamente ao papel de "disseminador de justiça social", ${ }^{10}$ como aquele desempenhado no contexto econômico e político do governo populista, a Justiça do Trabalho atuava aqui com forte propensão a beneficiar os empresários, seja quando era conivente com uma política de estabilização econômica pela via da contenção salarial, quando as empresas podiam repassar para os preços suas intenções de lucro, seja quando estas recorriam à proteção policial contra as manifestações operárias. Segundo Noronha (1998), o período militar representou uma ruptura com os aspectos populistas do regime Vargas porque não havia entre os novos governantes nenhuma intenção cooptativa como a que se buscou na tradição autoritária dos anos de 1940 e 1950.

A ação repressiva sobre os movimentos trabalhistas, a liberdade para demitir e o controle manipulado dos salários fizeram ampliar o grau de exploração da força de trabalho no interior das empresas, que aproveitavam o clima político autoritário para endurecer, ainda mais, a disciplina e o controle sobre os trabalhadores (Humphrey, 1982; Leite, 1992). As greves em grande escala nas cidades industriais de Contagem, Minas Gerais, e Osasco, São Paulo, em abril e julho de 1968 representaram uma tentativa de contraposição a este autoritarismo, logo, então, reprimida pelo regime militar. Organizadas a partir das bases e opondose diretamente ao Estado, essas greves prenunciariam as manifestações operárias que dez anos depois pressionaram a abertura política do país.

\section{Abertura política e novo sindicalismo}

Ao tempo em que o país experimentava seu principal surto de crescimento, alavancado pelos elevados índices de produtividade dos setores mais dinâmicos da economia, a gestão despótica sobre a força de trabalho no interior das empresas e o controle oficial rígido sobre os salários fomentavam terreno fértil para a manifestação das insatisfações operárias reprimidas pelo regime mi- litar. A onda de greves que se desencadeou por todo país a partir de 1978-1979, lideradas pelos metalúrgicos do $\mathrm{ABC}$ paulista, representou o transbordamento daquelas insatisfações e a manifestação pública dos trabalhadores, que participavam em massa, fortemente apoiados por movimentos populares organizados pelas alas progressistas da igreja católica e por uma militância de esquerda saída da surdina. O grito de luta era uníssono: contra a exploração econômica das empresas e a ditadura política dos militares. E teve alcance longo e de significado muito mais profundo para o desenrolar das transformações que a década de 1980 experimentaria: buscava a autonomia e a desvinculação dos sindicatos da tutela estatal e a retomada dos direitos políticos e civis cassados pelo regime militar.

Por trás das reivindicações salariais, as lideranças operárias surgidas daqueles movimentos tanto questionavam a legitimidade da representação meramente burocrática e assistencialista a que havia sido resumida a atuação dos sindicatos sob o regime militar, como negavam e criticavam as práticas populistas do sindicalismo no período precedente ao golpe. O chamado novo sindicalismo surgia enraizado nas bases, pelo confronto direto com os patrões e o Estado, reivindicando a negociação coletiva, a representação nos locais de trabalho, o direito de greve, ao mesmo tempo em que encabeçava os movimentos sociais pela redemocratização do país. Em São Bernardo e Diadema, berço desse movimento, pólo de concentração de grandes massas de trabalhadores empregados nas modernas indústrias automobilísticas, a revitalização da organização coletiva nos locais de trabalho fortalecia as inúmeras formas de resistência e mobilização, e encontrava na greve a sua maior arma de pressão. Num momento em que o desgaste político e econômico do governo tornava elevados demais os custos sociais da repressão, as greves de 1978, 1979 e 1980, embora duramente reprimidas, alcançaram dimensão quantitativa e ideológica suficiente para se espalharem por todo país e evolvendo diversas categorias. Entre 1978 e 1988 o número de greves bate recorde mundial, cumulando neste último ano, 132 milhões de jornadas de trabalho perdidas (Noronha, 1991), um forte indicativo de que o movimento trabalhista crescera, buscando seu espaço e impulsionando a distensão política do país. 
O novo sindicalismo trouxe à tona, também, o questionamento da estrutura corporativa e da prática sindical consagrada desde a era Vargas. Um questionamento que alimentou divergências dentro da própria direção oficial dos sindicatos, fazendo emergir lideranças identificadas com as bases e legitimadas por elas. Esses líderes ficaram conhecidos como os sindicalistas autênticos, por sua proximidade com os trabalhadores de chão de fábrica e sua orientação e ação voltadas para os problemas ali encontrados. Inaugurando um estilo de ação sindical combativo e apoiado pela militância e pela mobilização ativa das massas de trabalhadores, os sindicalistas autênticos tomavam expressão nacional sob a liderança carismática de seu principal protagonista - Lula -, acontecimento que, nas palavras de Sader (1988), fazia entrar na cena política novos atores sociais. É dessa militância e das principais correntes políticas e ideológicas em que ela se fragmenta que surgem o principal partido de esquerda do país, o Partido dos Trabalhadores (PT), e as duas mais importantes centrais sindicais, a CUT e a CGT, hoje, depois de sucessivos rachas internos, majoritariamente concentrada na Força Sindical.

Esse padrão combativo de ação sindical, que encontraria especialmente na CUT o apoio ideológico e logístico, seria sentido principalmente no fortalecimento da resistência ao poder arbitrário das gerências na organização do processo de trabalho, o que forçou a abertura de canais de negociação direta entre trabalhadores e patronato, deslocando a resolução dos conflitos para o interior das empresas. Aspectos do trabalho até então de domínio exclusivo da gestão capitalista, como controle disciplinar, ritmos de produção, regras de promoção, estabilidade, distribuição de horas extras, condições de higiene e segurança no trabalho etc., passaram a ser confrontados, pelo menos nos setores mais fortemente organizados, mediante a militância dos trabalhadores e a reivindicação crescente de espaços de intervenção diretamente barganhados. Conseqüência dessa militância é que os acordos coletivos ganham vida e novo sentido a partir da incorporação de reivindicações relacionadas aos interesses de maior penetração dos sindicatos nos locais de trabalho e a ampliação de seu poder de representação interna.
Mesmo à custa de muita resistência por parte dos patrões, a figura dos delegados de base, as comissões de representação interna dos trabalhadores, as comissões de fábrica, os comandos de greve e os grupos de negociação constituíram atores novos a demandar poder de voz e a criar uma nova institucionalidade no padrão de relações de trabalho, fazendo emergir conflitos latentes e trazendo a sua resolução para dentro das fábricas, longe dos tribunais do trabalho. Negociações coletivas, que antes meramente acompanhavam as formalidades da implantação de ajustes salariais definidos pelo governo, passaram, então, a incorporar, ainda que de forma descentralizada, reivindicações a respeito de abonos salariais e produtividade, demandas relativas à carreira e à estabilidade no emprego, redução da jornada de trabalho, igualdade de salário para mesmo trabalho, igualdade de salário e de tratamento entre os sexos, condições de segurança e saúde do trabalhador etc. Como argumentou Almeida, "a ação grevista descentralizada serviu para ampliar o espaço e o escopo da negociação coletiva, assim como para estender, a contrapelo da lei, direitos trabalhistas importantes" (1988, p. 337).

O coroamento dessas lutas veio com a Constituição de 1988, com a legalização de algumas conquistas centrais, de há muito reivindicadas e mesmo de certa forma já em prática, tanto no âmbito da representação de interesses - direito de greve, liberdade para a criação de sindicatos sem a tutela estatal, restauração do poder de negociar diretamente com os patrões, institucionalização dos delegados de base, entre outros -, como no âmbito da ampliação de direitos sociais e trabalhistas redução da jornada de trabalho de 48 para 44 horas, seguro desemprego, licença gestante de 120 dias, licença paternidade. Contudo, deve-se assinalar que, se a Constituição eliminou vários princípios autoritários encontrados na CLT, ela manteve alguns dos seus principais traços corporativistas: a unicidade sindical e a contribuição sindical obrigatória, que o novo sindicalismo tanto combateu. ${ }^{11}$

Embora se renovando por dentro (Cardoso, 1999), o novo sindicalismo não foi capaz de mudar a face extremamente fragmentada da representação sindical no país. O impulso inicial dos sindicatos mais fortes de expandir conquistas trabalhistas para diversas outras categorias represen- 
tadas por sindicatos pequenos e fracamente organizados, especialmente no tocante à defesa de reajustes salariais centralizados, foi perdendo fôlego à medida que as empresas recompunham suas políticas de produção e gestão do trabalho e que a economia entrava em trajetória declinante, em relação às acentuadas taxas de crescimento do período do milagre econômico. As greves dos anos de 1980 foram fundamentais para impedir prejuízos maiores quanto ao nível de renda, mas não foram suficientes para incorporar conquistas mais generalizadas no plano da redução das desigualdades sociais e econômicas. Negociações coletivas descentralizadas, reflexo mesmo das delimitações estruturais do sistema de relações de trabalho, impediram uma maior homogeneização das conquistas no que se refere ao nível de emprego e ao padrão de distribuição de renda e bem-estar, o que veio a ampliar a já histórica/estrutural heterogeneidade do mercado de trabalho no país. As centrais sindicais encontraram enormes dificuldades para articular formas de representação política mais amplas, capazes de influir significativamente nas decisões governamentais de política econômica e social, sobretudo no âmbito das políticas redistributivas (Almeida, 1988; Medeiros, 1994; Oliveira, 1994; Comin, 1994).

Alguma articulação conjunta, ainda que efêmera e de amplitude limitada, foi realizada no âmbito das câmaras setoriais com os acordos do complexo automotivo já no início dos anos de 1990. As centrais sindicais, com destaque para atuação ativa da CUT, tiveram papel relevante nas negociações. A experiência mostrou que, pela primeira vez, buscava-se um entendimento entre Estado, empresários e trabalhadores em torno da defesa de interesses mútuos no seio de um projeto de política industrial que contemplava questões de modernização produtiva, competitividade, nível de renda e emprego e contenção inflacionária, entre outras (ver, por exemplo, Diniz, 1994). Mas a agregação e a conciliação de interesses dos diversos grupos econômicos em torno de políticas públicas de alcance mais generalizado encontrava enormes barreiras na grande diferenciação de seu poder de organização e pressão, isso tanto para as entidades de trabalhadores como para as patronais. As profundas diferenças econômicas setoriais e regionais, coadunadas com os fracassos sucessivos dos planos de estabilização econômica, inviabilizaram as tentativas de ação cooperativa e solidária entre os sindicatos, debilitando seu poder para negociar, de forma mais homogênea, políticas de emprego e renda e mecanismos que assegurassem direitos mínimos de representação coletiva, tanto nos locais de trabalho, como nas cúpulas estatais (no âmbito dos três governos) de formulação de políticas públicas.

Essa questão remete todo tempo à luta por mudanças efetivas no sentido da democratização do sistema de relações de trabalho no país, o que contempla não apenas as instituições formais e legais da representação, mas também todo um complexo de práticas, regras, costumes e valores que instruem e orientam as relações pessoais e a regulação social do trabalho onde ele se realiza. No âmbito mais macro, por um preceito institucional não derrubado, em função não apenas das polêmicas e das divergências corporativas no interior das próprias entidades sindicais, mas também das fortes resistências e retaliações articuladas pelo patronato, as centrais sindicais não conseguiram institucionalizar o poder para negociar e assinar contratos de trabalho, o que, de outro modo, ampliaria o poder de negociação para os trabalhadores em qualquer dos espaços econômicos/geográficos (setorial, regional ou nacional) em que um possível contrato coletivo de trabalbo se estabelecesse. Da mesma maneira, não foi outro o desempenho geral da representação sindical, espalhada numa complexa malha de pequenos sindicatos municipais, incapazes de aproveitar a própria estrutura federativa para o fortalecimento das negociações setoriais no sentido de incorporar um padrão mais homogêneo e universal de relações de trabalho. ${ }^{12}$

Produto dessa mesma heterogeneidade, os avanços democráticos no plano mais micro das relações de produção também ocorreram de forma desigual. É verdade que a redemocratização do país passou a exigir uma redefinição das relações de trabalho no interior das empresas, fazendo-as encarar o conflito de classe. Mas os condicionantes históricos do autoritarismo e as vicissitudes econômicas embaladas pela persistência de ciclos recessivos tiveram papel decisivo no enfraquecimento das disputas. As concessões não vieram sem a forte oposição capitalista. O extremo conservadorismo dos patrões, a complacência da própria Justiça do Trabalho (Humphrey, 1982; Leite, 1992; Mangabeira, 1993) e mesmo o titubeio das lideranças sindicais, 
cautelosas com o surgimento de organizações de base autônomas, ou receosas da manipulação desses grupos por parte das gerências, tornaram muito lento o avanço da democracia na produção. Muitos sindicatos, inclusive os novos, criados no calor dos movimentos de início da década, continuaram predominantemente atuando como "sindicatos de porta de fábrica", sem qualquer acesso aos locais de trabalho, apegados às práticas assistencialistas e cuja legitimidade para negociação é encontrada apenas no poder de homologação legalmente conferido (Boito Jr., 1991; Oliveira, 1994). Em outras palavras, os avanços nos espaços de disputa e negociação das políticas de produção nos locais de trabalho foram moderados, especialmente quando se considera o grande universo de trabalhadores empregados em empresas tradicionais que pouco se empenharam na modernização de suas práticas de relações industriais, que podem contar com um vasto e competitivo mercado de trabalho de baixa qualificação e que formam as bases de sindicatos politicamente mais fracos.

Contrariamente aos anos de 1980, quando a defesa das reposições salariais ante as altas taxas inflacionárias instigava e legitimava a ação confrontacionista dos sindicatos com as empresas, orientando, inclusive, as discussões ideológicas e os posicionamentos das centrais quanto às políticas do governo, nos anos de 1990 esta postura confrontacionista perde fôlego, dando lugar à política de negociação e cooperação entre capital e trabalho em torno de projetos mútuos e específicos de autopreservação que a nova conjuntura econômica exigia. A reestruturação produtiva nas empresas faria do desemprego o grande vilão do processo de retração dos sindicatos e do avanço de iniciativas empresariais e do governo no tema da flexibilização do mercado de trabalho. Vejamos, então, este novo contexto.

\section{Neoliberalismo e retrocesso nas relações de trabalho}

Os anos de 1990 marcaram transformações profundas na economia brasileira. Com a vitória eleitoral de Fernando Collor de Mello em 1989, primeiro presidente escolhido em eleição direta após o regime militar, o país incorporava uma agenda de ajustes econômicos que trazia em seu bojo a abertura comercial e as privatizações. A isso se agregava a busca da estabilidade econômica, pedra de toque dos dois governos de Fernando Henrique Cardoso. A abertura econômica, iniciada de forma atabalhoada com a queda abrupta das tarifas de importação para uma grande diversidade de produtos industriais, trouxe consigo o incremento do discurso da competitividade (agora em níveis internacionais), precipitando a entrada da fechada economia brasileira na circulação da rede global. Isso fez com que, forçosamente, fossem expandidos os processos de reestruturação produtiva: fechamento de fábricas, renovação tecnológica, terceirização, subcontratação, reorganização dos processos produtivos, enxugamento de quadros, entre outros, traduziram os ajustes. Em todos os casos os esforços se concentrariam primordialmente na racionalização de custos, com destaque para os custos do trabalho. Tais processos de reestruturação aconteceram concomitantemente a uma conjuntura recessiva, que se aprofundava, e a uma avalanche de medidas liberais concretizadas nos programas de privatização e no abandono das políticas públicas voltadas para a expansão da demanda, com acento no controle da moeda e da inflação, via elevação da taxa de juros, e no avanço de projetos de desregulamentação econômica e flexibilização institucional do mercado de trabalho. Resultado imediato dessas mudanças: até a primeira metade dos anos de 1990 mais de 1 milhão de empregos foram destruídos na indústria de transformação, tendo boa parte de seus trabalhadores caído na informalidade e outra se deslocado para o setor de serviços, onde é ainda mais forte a heterogeneidade das condições de emprego, com predomínio (para) dos (os) contratos de baixa qualificação e de baixos salários (Medeiros e Salm, 1994; Pochmann et al., 1998).

Além do desemprego crescente, leis federais apoiadas no ideário de que a liberdade para contratar e demitir ajustaria eficientemente os abismos diferenciais entre a oferta e a demanda de trabalho davam vazão a institutos que fragilizavam ainda mais a proteção do trabalho. A retórica concentrava-se no anacronismo e na desfuncionalidade da legislação trabalhista ainda proveniente da era Vargas. Para muitos analistas do sistema de relações de trabalho (ver, por exemplo, Pastore, 1994), para os empresários, para o governo e 
para algumas lideranças sindicais, aquela legislação não acompanhava o passo das transformações econômicas e produtivas necessárias ao ajuste competitivo do país. O caminho da "modernidade" passava pelas agressivas reformas no âmbito das privatizações, da previdência, da desregulamentação dos mercados econômico e de trabalho. Neste último, a saída, então, era flexibilizar os estatutos que, segundo eles, oneravam o custo do trabalho e inviabilizavam a geração de empregos. Foi, portanto, com esse propósito que, no segundo governo de Fernando Henrique Cardoso, editou-se um pacote de medidas legislativas que alterava regras trabalhistas básicas, como o vínculo contratual, a jornada e o salário. Assim, o contrato de trabalho por tempo determinado, o trabalho em tempo parcial, a suspensão temporária do contrato de trabalho por motivos econômicos, o banco de horas, a participação nos lucros e resultados das empresas, a redução do salário com redução da jornada, entre outros, passaram a fazer parte do rol de possibilidades legais de mudança nos contratos de trabalho. Em seu conjunto, essas medidas representaram um verdadeiro desmonte dos direitos de proteção ao trabalho e um retrocesso no espaço recentemente conquistado pelo movimento sindical. ${ }^{13}$

A promessa da geração de empregos, todavia, não se concretizou. ${ }^{14}$ Mas os ataques neoliberais às instituições do trabalho pareciam vivamente abrir caminho para uma reprivatização das relações de trabalho. Ao findar seu governo, FHC fez passar no Congresso o Projeto de Lei 5.843/01, que propunha a alteração do artigo 618 da CLT, cujo objetivo era fazer sobrepor os acordos coletivos privados ao que determina a legislação trabalhista. Esse projeto sai de pauta no governo Lula, mas, como veremos, parece não ter esmorecido o teor liberalizante que ronda as intenções da reforma trabalhista acenada pelo novo governo. Em outras palavras, as políticas de inserção da economia brasileira no comércio internacional seguiram à risca a cantilena dos valores superiores do mercado na ordenação da economia, e seguiram uma tendência mundial. É vasta a literatura que aborda o desmonte das estruturas políticas e sociais que possibilitaram o crescimento dos países desenvolvidos nos chamados anos dourados do capitalismo, desmonte este forte- mente centrado nas instituições do mercado de trabalho e nas políticas de bem-estar social. Aspectos contundentes das mudanças foram a ampliação das formas atípicas e precárias de ocupação e o crescimento do desemprego, fenômenos que fizeram romper duas regras básicas do padrão de regulação precedente: a estabilidade e a jornada de trabalho preestabelecida. ${ }^{15}$

No entanto, o debate das reformas neoliberais no Brasil põe em foco questões sociais e políticas muito mais complexas, dada as características autoritárias, precárias, excludentes e desiguais que marcaram o nosso sistema de relações de trabalho e a nossa estrutura social. Antes de ser pensado no seio de um projeto mais amplo de desenvolvimento e integração, ele preconizava escolhas políticas com forte propensão a acentuar aquelas características, nas palavras de Siqueira Neto: "vulgarizando o conceito de rigidez do direito e do mercado de trabalho e banalizando a negociação coletiva e o papel do estado" (1996, p. 328). Deslocava-se, assim, as discussões e as mobilizações em torno, por exemplo, de uma possível redução da jornada de trabalho como política socialmente mais justa de geração de emprego, e, inclusive, deslocava-se o velho debate em torno da reforma do sistema corporativo e seus anseios por tornálo mais democrático, em proveito da desregulamentação dos direitos sociais e da flexibilização das relações de trabalho (Oliveira, 1994; Rodrigues, 1999). Atacava-se como rígido um sistema de regulação que estruturalmente sempre se adaptou a todo tipo de conjuntura econômica pelos artifícios oficiais ou clandestinos que tornam extremamente flexível o uso do trabalho no país.

O outro lado da moeda do debate e das práticas de flexibilização é que se tornaram cada vez mais unânimes as análises que apontam para uma redução significativa do emprego formal e sua expansão na esfera da informalidade. A participação dos empregados formais cai de 53\%, em 1991, para 45\%, em 2000. Em contrapartida, o grau de

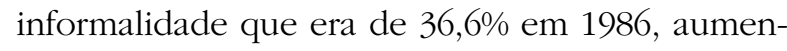
tou para 37,6\%, em 1990, e para 50,8\%, em 2000 (Sabadini e Nakatani, 2002; Cacciamali, 2000). Embora deva ser considerada a heterogeneidade das situações que consubstanciam o trabalho informal, o fato é que sua expansão tem se dado num contexto de forte desestruturação do mercado formal, 
com crescimento significativo dos trabalhadores sem carteira de trabalho assinada, portanto, à margem dos direitos assegurados na legislação e fora de qualquer relação com os sindicatos, único meio de representação institucional.

As demissões em larga escala dos anos de $1990,{ }^{16}$ a difusão no interior das empresas de programas organizacionais voltados para a antecipação dos conflitos e o maior envolvimento ideológico dos trabalhadores (especialmente no âmbito dos programas de qualidade total), a migração de trabalhadores do setor industrial (tradicionalmente mais organizado em sindicatos e desfrutando relações de trabalho formal) para o setor de serviços (caracteristicamente mais heterogêneo e onde predominam relações de trabalho mais precárias e instáveis, portanto, de baixa organização sindical), tiveram conseqüências avassaladoras sobre o nível de sindicalização e sobre o poder (ideológico e material) dos sindicatos, compondo uma realidade muito mais complexa para as relações de trabalho que não mais poderia ser enfrentada pela prática confrontacionista do passado (Oliveira, 1994; Comin e Castro, 1998; Rodrigues, 1999).

É preciso destacar, no entanto, e como mais um condicionante das mudanças na correlação de forças, a importância política da polarização na cúpula do movimento sindical, polarização esta que foi decisiva na sustentação do projeto neoliberal que orientou as escolhas políticas dos três governos nos anos de 1990. Trata-se da emergência da Força Sindical como central que propunha uma alternativa de ação e de pensamento político em direta oposição à prática combativa e aos ideais transformadores da CUT. Criada em 1991 e reunindo egressos do velho sindicalismo de Estado, essa central incorporava aquele discurso da modernidade, já entoado pelo governo e pelas elites empresarias. Atribuindo a si o slogan de um sindicalismo moderno, a Força Sindical defendia um sindicalismo de resultados, assente à racionalidade cega do livre mercado, e desideologizado, no sentido de que circunscrito aos interesses econômicos imediatos dos trabalhadores. Embora moderadamente reivindicativa no plano econômico, sua atuação pautava-se na cooperação e na parceria com o capital, numa negação explícita ao sindicalismo de confronto, ideologizado (porque tinha como uma de suas metas o questionamento do capitalismo e das investidas neoliberais), propugnado pela CUT, baluarte do movimento sindical nos anos de 1980 e, na época, principal opositora do governo. ${ }^{17}$

Efeito dessa divisão, destruidora do poder do sindicalismo (Giannotti, 2002) e fomentada pelas forças conservadoras no poder, foi que as negociações se voltaram para a realidade e para a possibilidade específica de cada empresa ou de um conjunto de empresas em determinado setor, perdendo o elo de referência que, de alguma forma, existiu quando a luta por reposição salarial e pela abertura política promovia uma articulação mais abrangente entre todas as categorias. Por seu turno, o desemprego e a negociação de mecanismos mínimos que assegurassem alguma estabilidade provisória, à falta de uma legislação mais ampla, passaram a assumir relevância na agenda sindical.

É esse padrão de negociação, emerso de um contexto de estabilidade monetária, de livre negociação dos salários e de mudanças na estrutura produtiva e na organização e gestão do trabalho dentro das empresas, que fez autores como Castro (1995 e 1997), Comin e Castro (1998) anunciarem o surgimento de uma nova institucionalidade micro-regulatória, segundo a qual novos parâmetros, novas regras, em novos terrenos e escopo, comporiam os contratos coletivos de trabalho e os aparatos normativos interno às empresas. A preservação dos empregos, as políticas de formação e qualificação, o deslocamento de ajustes salariais fixos para formas variáveis de compensação salarial, a manutenção de conquistas passadas, a flexibilização das jornadas etc. passaram a dar o tom das negociações coletivas, com o poder da balança de forças desfavorável para os trabalhadores. ${ }^{18}$ O grande dilema, porém, como destacou Oliveira (1994), é que a área de incidência desses novos temas ou desse novo campo de pactuação é a empresa, onde tradicionalmente a organização sindical sempre foi débil, e, acrescentese, onde ela passa a concorrer com as iniciativas das empresas de buscarem a cooperação dos trabalhadores, normalmente isolando-os do sindicato. As negociações neste caso dificilmente poderiam ser embasadas em condições ou posições de mútua autonomia, abrindo espaço para as decisões unilaterias. 
Flexibilização da CLT: perda de direitos e maior precarização das condições de trabalho

Se as negociações coletivas avançaram a ponto de extrapolar a CLT e passaram a incorporar interesses específicos e mesmo individualizados, quebrando a rigidez daquele estatuto mais amplo em aspectos da regulação do trabalho que as novas exigências competitivas tornaram obsoletos (ver, por exemplo, Castro, 1997; Cardoso, 1999), não se pode estagnar na rigidez de um tipo de representação (descentralizada por completo, extremamente fragmentada e longe das empresas) que impede o fortalecimento do poder de negociação dos trabalhadores. É essa rigidez que clama, como defendem as centrais sindicais e muitos analistas do sistema de relações de trabalho no país, por mudanças efetivas e democráticas na estrutura corporativa e na CLT. O contexto das reformas institucionais, no entanto, tem sido adverso para os trabalhadores em todo o mundo. Seja no âmbito da reforma trabalhista, da previdência, da tributária, seja na esfera da redefinição das políticas sociais do Estado, seu sentido é o de reafirmar o primado do liberalismo.

O governo Lula manteve a promessa de reformular a CLT, mas a despeito de toda expectativa de reversão da política econômica dominante nos últimos dez anos não rompeu com aquela tendência, e mesmo, contrariando princípios ideológicos de toda uma luta de esquerda no país, abriu mão de propostas mais revolucionárias. No entanto, contrariamente à conduta fechada com que foram definidas as mudanças institucionais no governo anterior, chamou os interessados para o debate. Com este fim, e para a construção das propostas, foi instituído, no início de 2003, o Fórum Nacional do Trabalho (FNT), uma entidade tripartite de negociação em que participam representantes do governo, das centrais sindicais e dos empresários. O FNT privilegiou inicialmente a discussão sobre a reforma da estrutura sindical, uma certa preparação do terreno para o encaminhamento da reforma das leis trabalhistas. A primeira etapa dos debates foi concluída com o Relatório da Comissão de Sistematização, em março de
2004, e é este o projeto que deverá ser apreciado pelo Congresso.

Embora a divulgação dos trabalhos do FNT tenha ressaltado um expressivo consenso quanto às propostas, há elementos polêmicos e questões importantes que devem encontrar resistência para sua aprovação. As duas mudanças mais radicais, um tanto contraditórias em seus propósitos, e que podem sintetizar o teor desta etapa da reforma, são, de um lado, a institucionalização do poder de negociação das centrais sindicais, o que em tese e positivamente abriria espaço, pela primeira vez no país, para um maior poder de pressão e homogeneização das demandas dos trabalhadores; de outro, a legalização do pluralismo, ou seja, a consagração de uma visão de democracia liberal a ordenar a estrutura organizativa dos sindicatos.

O projeto de reforma sindical põe em evidência a velha demanda pelo fim do monopólio da representação ao estabelecer a possibilidade de se ter legalmente mais de um sindicato em uma mesma base de representação. Para obter a exclusividade na negociação (que pode ser derrubada na disputa), o sindicato ou qualquer organização de nível superior deverá atingir critérios de representatividade, entre eles, o de possuir pelo menos $20 \%$ dos sócios na sua base. Ainda que esse sistema pretenda reduzir a enorme fragmentação a que foi levada a estrutura representativa, principalmente depois da explosão na criação de sindicatos nos anos de 1980, ele aponta riscos pelo fato de poder desencadear uma competição destruidora na corrida dos sindicatos pelo poder de representação dos trabalhadores, questionando o próprio preceito que supostamente motivou o projeto de reforma, qual seja, o de fortalecer aquela estrutura e seu poder para congregar os interesses dos trabalhadores. ${ }^{19}$

O pluralismo na representação talvez seja o ponto mais polêmico da reforma e que deverá encontrar resistências dentro do próprio movimento sindical devido à ameaça que pode representar à sobrevivência de muitos sindicatos. Um outro ponto polêmico diz respeito ao grau relativo de autonomia que caberá aos sindicatos, uma vez que a legalização do poder de negociação das centrais embute o perigo da super concentração de poder na cúpula sindical. Essa questão, também relacionada à definição do nível e da abrangência das ne- 
gociações, deve alimentar divergências dentro das estruturas de poder já estabelecidas, como no caso da relação entre as centrais e as confederações, as quais não participaram do fórum do trabalho.

Um outro aspecto polêmico da reforma sindical que será encaminhada ao Congresso é que ela deixa brechas para a interpretação de que o negociado deve prevalecer sobre o legislado. Numa passagem do Relatório da Comissão de Sistematização (2004, p. 32) em que se estabelecem os princípios do processo de negociação, há uma referência ao "não cerceamento do processo de negociação coletiva pela lei”, princípio que, quando transformado em linguagem jurídica, pode traduzir-se naquela malfadada intenção de alterar o artigo 618 da CLT; uma temeridade quando se tem sindicatos debilitados pelo fantasma do desemprego. O mesmo argumento pode ser levantado em relação ao tratamento preferencialmente dado ao tema da composição dos conflitos. Embora não seja descartada a arbitragem da Justiça do Trabalho, há forte tendência de se privilegiar as instâncias privadas de conciliação e mediação, com assistência dos sindicatos; o temeroso, aqui, como a experiência já demonstrou para o caso das Comissões de Conciliação Prévia, são as possibilidades de manipulação, de indução aos acordos lesivos e do abrir mão de direitos, quando mais prevalece a necessidade de preservação do emprego.

Há, no entanto, aspectos positivos na proposta de reforma, a exemplo da criação do Conselho Nacional de Relações de Trabalho, uma câmara de negociação tripartite e paritária que poderá possibilitar uma maior abertura dos espaços de proposição de políticas públicas e de iniciativas legislativas na área das relações de trabalho; um avanço em relação à tradição autoritária, centrada no Executivo, com que desde os anos de 1930 se definiu a política de relações de trabalho no país. Um outro aspecto positivo é o indicativo de legalização da representação nos locais de trabalho, uma demanda antiga do movimento sindical que sempre esbarrou na resistência patronal e, por isso mesmo, embora o Relatório Final da Comissão de Sistematização subscreva que houve concordância entre as partes a respeito do reconhecimento deste direito, não prevê definição clara das regras de sua regulação.

Ainda que a proposta de reforma da CLT acene com avanços importantes - como o poder de negociação das centrais, a representação de base, o reconhecimento e a regulação do direito de greve, a proibição de práticas anti-sindicais -, o seu acento numa dinâmica que privilegia a lógica de mercado enseja cuidados e exige pressão dos trabalhadores para que não seja aprovada uma reforma que camufle perdas potenciais, especialmente porque na segunda etapa dos trabalhos do FNT estará em jogo a mudança do parâmetro institucional que define os direitos individuais dos trabalhadores, a reforma trabalhista.

Não custa ressaltar que nem os aspectos estruturais, nem a dinâmica conjuntural parecem ser favoráveis a mudanças que façam retroceder o ímpeto de retirada de direitos que tem acompanhado as reformas trabalhistas em todos os países. Propostas importantes e que apontariam uma luz no fim do túnel da precarização e do desemprego, como a redução da jornada de trabalho ou a discussão da reforma dentro do marco mais amplo de um projeto de desenvolvimento centrado na elevação do padrão de renda e de welfare dos trabalhadores, são ridicularizadas e tratadas como insanas em face das necessidades urgentes da competição. Ao contrário, os empresários vão insistir no argumento de alteração do art. 618 da CLT, no sentido de sacramentar a lei do mais forte, e o discurso da rigidez é sua principal arma ideológica: a flexibilização requerida é aquela que derruba direitos. Ora, em nenhum dos seus dispositivos a CLT impede a incorporação de vantagens ou a negociação de expedientes que mantenham ou ampliem conquistas. Ao contrário, garante uma base mínima de direitos contra a exploração que, como vimos, foram conquistados mediante longos processos de luta política. Fazer prevalecer o negociado sobre o legislado implica legitimar a redução e a manipulação daquela base mínima de direitos. ${ }^{20}$

Ademais, há um outro agravante. Como o que prevalece no país é uma prática de elevada rotatividade, em razão mesmo da ausência de proteção legal à estabilidade e à representação interna, a Justiça do Trabalho não resolve problemas entre empregados e empregadores, e, sim, entre desempregados e empregadores: os trabalhadores não reivindicam direitos durante a relação de emprego pelo medo de as empresas os demitirem, como é comum acontecer. Neste caso, como bem lembrou o jurista José Alberto Maciel (O Globo, 
7/3/2002), o trabalhador não vai à Justiça do Trabalho via sindicato, que fez o acordo, vai individualmente, portanto, sem poder de barganha. Decorre disso que o que está em jogo, efetivamente, é a garantia de direitos ou a possibilidade de seu rebaixamento, sem esquecer que a proposta de privilegiar a conciliação e a mediação em âmbito extrajudicial pode representar, nestas condições, uma ameaça àquela garantia. Ainda nas palavras do jurista, não estaríamos, pois, numa situação de flexibilização do trabalho e sim de uma desregulamentação, que significa retirada de direitos.

A afirmação é ainda mais válida para aqueles trabalhadores representados por sindicatos que possuem fraca tradição de confronto e em cujas jurisdições se encontram empresas que pouco ou nada investiram na valorização de seu pessoal. Isso, a curto ou médio prazo, seria muito pouco revertido, a despeito da reforma na estrutura sindical. Como conseqüência, considerando a extrema heterogeneidade estrutural do mercado de trabalho no país, apenas alguns segmentos do trabalho organizado estariam em condições de negociar junto aos interesses do capital com certo poder de barganha (ver, por exemplo, Castro, Comin e Leite, 1999; Carvalho Neto, 2001). Para os setores econômicos de sofrível desempenho e de fraca representação sindical, ${ }^{21}$ a legislação trabalhista e a função sancionadora do Estado na garantia de seu cumprimento continuam sendo os principais institutos, senão os únicos, a supostamente assegurar limites mínimos aos critérios de contratação e uso do trabalho (salário-base, teto para as jornadas, remuneração das horas-extras trabalhadas, $13^{\circ}$ salário, proteção às gestantes e ao trabalho infantil etc.). E isto, em tese, já que, ainda hoje, é imprescindível que muitos sindicatos "corram atrás" para fazer as empresas respeitarem esses direitos básicos do trabalhador.

Para os trabalhadores empregados em tais setores, a reestruturação produtiva - pensada aqui como qualquer mudança posta em prática pelas empresas como forma de adaptação competitiva às demandas do mercado - e a flexibilização da CLT já realizada no governo FHC têm se revertido em processos de perdas salariais e sociais, de intensificação das jornadas e dos ritmos de trabalho, de controle disciplinar por meio da ameaça de demissão (Costa, 2002), aspectos que, associados ao praticamente inexistente poder de representação interna, dificultam um ambiente de efetiva negociação com os patrões. A postura conciliadora, e não a confrontacionista, é a regra, uma vez que importa assegurar o próprio emprego, mas a negociação se submete às possibilidades de concessão alegadas pelas empresas e a cujos parâmetros os sindicatos não têm acesso. Por isso mesmo que a CLT ainda é o parâmetro central do espaço que se abre para a negociação, assim como a referência que impede que ela resvale na pura mercantilização da força de trabalho, sem contar que ela é também a grande referência para as relações de trabalho não cobertas pelo vínculo da formalidade (ver Noronha, 1998). É nesse sentido que, para grande maioria dos trabalhadores, as mudanças implementadas ou estimuladas na legislação trabalhista podem significar a ampliação do nosso velho padrão despótico de relações de trabalho.

\section{Notas}

1 Limito-me a caracterizar, muito genericamente, o modelo corporativista de relações de trabalho. A literatura que o estuda é tão vasta quanto variáveis foram os debates ideológicos e as conjunturas econômica e política que acompanharam o processo de industrialização e de organização sindical no país. Entre os mais consolidados e leitura obrigatória para o entendimento da época e dos condicionantes de sua institucionalização temos: Evaristo de Moraes Filho (1978), Azis Simão (1966), Albertino Rodrigues (1968), Leôncio Martins Rodrigues (1974), Luiz Werneck Vianna (1999), Maria H. Tavares de Almeida (1988), Francisco Weffort (1973), Wanderley Guilherme dos Santos (1979), Castro Gomes (1979, 2005), Araújo (1998).

2 É de Wanderley Guilherme dos Santos (1979, p. 29) o conceito de cidadania regulada, que mais à frente retomarei, segundo o qual, o Estado delimitava a esfera dos direitos sociais aos vínculos do indivíduo à esfera da acumulação. Só auferiam direitos previdenciários e só eram cobertos pelas leis do trabalho as pessoas legalmente reconhecidas pelo Estado como ocupando uma profissão, esta também reconhecida pelo mesmo.

3 Pensamos aqui no conceito de corporativismo tal qual o encontrado no clássico artigo de Schmitter (1974). Buscando um modelo para análise empíri- 
ca dos sistemas de representação política nos países industrializados e tomando como referência o voluntarismo e a liberdade das organizações pluralistas, Schmitter define corporativismo por exata oposição às características dessas organizações: número limitado de unidades de representação, compulsórias, não competitivas, hierarquicamente ordenadas, funcionalmente diferenciadas. O modelo comporta duas modalidades de corporativismo: o societário, em que os sistemas de representação são autônomos em relação às estruturas e ao poder do Estado; e o estatal, onde, embora as organizações de representação (associações, sindicatos) sejam institucionalmente reconhecidas, elas são mantidas como órgãos auxiliares e dependentes do Estado. O corporativismo societário estaria associado à realidade de países cujos sistemas políticos são mais democráticos, com fortes políticas de welfare; já o corporativismo estatal viria associado aos regimes políticos autoritários que acompanharam os projetos de substituição de importações nos países de capitalismo pouco desenvolvido. Stepan (1980), estudando a experiência de países como Brasil, México, Argentina e Chile, distingue em dois pólos os subtipos de corporativismo estatal: o inclusivo, em que a elite dominante, utilizando-se do aparato estatal, procura sustentar seu projeto de desenvolvimento e dominação pela incorporação parcial das classes trabalhadoras no modelo político-econômico; e o exclusivo, modelo em que a legitimidade do poder dominante e de seu projeto político-econômico é alcançado pelo apoio de políticas altamente coercitivas feitas para desarticular e depois reenquadrar grupos importantes da classe trabalhadora.

4 Meu interesse aqui se volta especificamente para os sindicatos de trabalhadores. A mesma lei regulamentou a estruturação das entidades representativas do interesse patronal, mas estas foram tradicionalmente e patrimonialisticamente agraciadas por canais informais e paralelos de representação e troca política junto às agências estatais, dos quais a representação do trabalho foi arbitrariamente excluída. Ver, entre outros, O’Donnell (1988) e Dinis (1994).

5 Embora a Constituição de 1988 tenha reduzido os procedimentos legais e burocráticos para a criação de sindicatos e eliminado ou reduzido o poder de intervenção direta na constituição das representações, nos estatutos e nas atividades administrativas ou de militância dos sindicatos, a prerrogativa legal do reconhecimento, o monopólio da representação e o imposto compulsório, que tornam a representação sindical uma outorga do Estado, constituem, ainda hoje, características autoritárias da estrutura corporativa, responsável pela subordinação dos sindicatos às cúpulas dos três poderes centrais do Estado (Boito Jr., 1991). Segundo esse autor, um efeito dessa característica estrutural, estável e ainda não modificada por falta de efetivo interesse dos próprios sindicatos, é que, sobre ela, a regulamentação ou a intervenção estatal pode se dar com rigor ou com flexibilidade, sendo sua intensidade definida pela configuração das relações de poder entre os atores sociais (capital e trabalho) em cada contexto conjuntural histórico.

6 O salário mínimo, base monetária da grande massa salarial no país e também referência para os outros patamares de salários, sempre foi definido pelo governo em função de seus projetos de controle da economia e de desenvolvimento nacional. Em sua Crítica à razão dualista, Francisco de Oliveira (1977) demonstrou como a instituição do salário mínimo no governo Vargas significou, na prática, um aviltamento do salário industrial, especialmente, do salário das ocupações mais qualificadas. Transformava-se, assim, num instrumento efetivo para a acumulação industrial, à medida que não tinha como referência a luta de classe ou qualquer critério de produtividade, e, sim, o mínimo necessário à sobrevivência do trabalhador.

7 É quase desnecessário lembrar do nosso precário e insuficiente sistema público de direitos sociais básicos (saúde, educação, previdência), além do fato de ele praticamente só ter abrangido todos os setores sociais nos anos de 1970. O seguro desemprego, por sua vez, só viria a ser implantado pelo governo Sarney com todas as limitações que lhes são inerentes, inclusive o fato de só terem acesso aqueles que já estiveram formalmente empregados. Para os que jamais assinaram uma carteira de trabalho, inexiste este direito cidadão.

8 Albertino Rodrigues (1968:19) define assim o peleguismo: "fenômeno gerador de dirigentes sindicais que se contentam com as atribuições legais e se tornam instrumentos dóceis para que a organização atue menos no interesse de sua classe do que no interesse particular da empresa econômica e da ordem política do momento".

9 O FGTS é um assunto extremamente polêmico desde sua instituição, não apenas por ser produto legislativo de regime autoritário, mas por ter se vertido num mecanismo estimulador de práticas predatórias de uso do trabalho. Ele facilita a alta rotatividade nas empresas, o que, entre outras conseqüências, di- 
ficulta a organização coletiva e a ação reivindicativa nos locais de trabalho, na medida em que as empresas podem demitir seus trabalhadores mais militantes. Para uma discussão recente sobre o poder de influência do FGTS na elevada rotatividade praticada pelas empresas no Brasil ver, por exemplo, Cardoso (1999).

10 Nos anos de 1940 e 1950, ainda que a base industrial não estivesse sido consolidada, a legislação trabalhista provocou tremendo impacto no mundo do capitalismo selvagem com que eram reguladas as relações de trabalho, em função mesmo da extrema resistência com que os patrões a receberam. Condições de trabalho e salário, até então arbitrariamente constituídas, passavam a ter respaldo legal de referência mínima. Leite Lopes (1988), estudando o sistema de fábrica têxtil com vila operária, mostra-nos de maneira brilhante como uma forma quase escravista de dominação é desmontada, de baixo, pela resistência incansável dos trabalhadores, com seus mais diversos recursos e estratégias de pressão, quando se alia à sua luta a Justiça do Trabalho. O recurso a este órgão constituía-se numa ação permanente do coletivo de trabalhadores, de maneira que a legislação trabalhista funcionava como que instruindo uma consciência de classe. Ela era o parâmetro e o respaldo legal orientador e legitimador da ação coletiva no interior das fábricas, muitas vezes, sem o conhecimento prévio, ou à revelia do sindicato. Mesmo a greve, na conjuntura política menos repressiva do correr dos anos de 1950 e primeiros anos da década de 1960, encarnava um sentido de justiça e legitimidade em face das humilhantes leis patronais disciplinares e à ultra exploração do trabalho.

11 Dentro do próprio meio sindical e no meio acadêmico/intelectual (ver, por exemplo, Almeida, 1988; Boito Jr., 1991), o novo sindicalismo deu panos para manga para o desenvolvimento de algumas controvérsias a respeito das mudanças estruturais efetivamente realizadas pelo movimento. As novas lideranças propunham uma ruptura não apenas com as práticas sindicais passadas, que qualificavam como mais próximas dos interesses político-partidários e pessoais das lideranças sindicais de então, do que dos efetivos interesses das massas de trabalhadores, mas propunham também uma ruptura com a própria estrutura corporativa. As polêmicas remetem à avaliação dos efeitos da ação sindical pós-1978 sobre o que se postulava como uma crise do corporativismo de Estado (Almeida, 1988), crise esta instigada pela proposição de sistemas alternativos, autônomos, mais abrangentes e democráticos de in- termediação e representação de interesses. O ataque das lideranças sindicais autênticas e das oposições, representadas pela CUT, dava-se sobre os princípios que inevitavelmente tornavam os sindicatos dependentes do Estado e, portanto, os incapacitavam objetivamente de seguir projetos autônomos de representação de classe, basicamente: a unicidade sindical, que se opunha ao pluralismo da representação e à liberdade de associação; e o imposto compulsório, que garantia a existência de sindicatos independentemente de seus esforços de legitimação e prestação de contas perante as bases. Águas passadas, em muito os sindicatos renovaram suas práticas, mas pouco ou nada ousaram mexer, a despeito dos inúmeros projetos de lei intentados pelo governo, nesses dois princípios corporativos fundamentais.

12 É preciso, todavia, destacar o avanço da participação das centrais sindicais, com poder deliberativo na formulação de projetos e aprovação da aplicação de recursos, em diversos fóruns institucionais no âmbito das políticas públicas (ver, por exemplo, Pochmann et al., 1998; Souza, Santana e Deluiz,1999); assim como é preciso destacar sua influência política/ideológica na orientação da ação sindical e das práticas de negociação. Mas há de se considerar também que são tremendamente complexas as possibilidades e as oportunidades de compatibilização e coordenação numa instância de meso ou macro-regulação, não tanto de interesses, tendo por base as carências sociais e o indiscutível baixo padrão de renda no país, mas das possibilidades objetivas de ação e concretização das reivindicações. Diferenças econômicas entre regiões, setores, empresas e no grau de organização política dos sindicatos dificultam enormemente a articulação e a negociação de grandes acordos coletivos centralizados.

13 Para entender o significado dessas principais medidas institucionais de mudança nas leis trabalhistas e seu efeito perverso na conquista de direitos dos trabalhadores, ver, por exemplo, Krein (1999).

14 Segundo dados do IBGE, em 1998 o desemprego atingia 7 milhões de brasileiros - 9,2\% da População Economicamente Ativa (PEA). Já em 2000, ele angustiava 11,5 milhões de trabalhadores, quase 15\% da PEA.

15 As iniciativas de reforma na CLT foram fortemente influenciadas pelas mudanças no mundo do trabalho provocadas pelo acirramento da competição capitalista global. Não temos espaço aqui para um aprofundamento dessa questão, mas cabe lembrar que os ataques neoliberais ao Estado e aos sindica- 
tos se deram com força diferenciada nos diversos contextos nacionais, em função mesmo da história política de suas instituições. Para uma análise das transformações econômicas e institucionais em alguns países europeus e nos Estados Unidos pósanos de 1970, ver, entre outros, Harvey (1994), Boyer (1995), Mattoso (1996), Dedecca (1996), Antunes (2000) e Costa (2000).

16 Segundo Mattoso (1999), a década de 1990 eliminou cerca de 3,3 milhões de postos de trabalho formais na economia brasileira, sendo boa parte deles $(1,8$ milhões) contabilizada depois de 1995, como decorrência das políticas neoliberais do governo FHC.

17 A Força Sindical surgia para rivalizar diretamente com a CUT e tinha nesse papel total apoio das lideranças empresariais, temerosas das pressões democratizantes então mobilizadas por essa central. Para nos retermos à temática mais fortemente focada aqui, vale ressaltar que a orientação política da Força Sindical, cuja principal base de sustentação se encontra no Sindicato dos Metalúrgicos de São Paulo (SMSP), teve papel decisivo na desregulamentação do mercado de trabalho, legitimada como alternativa possível de redução do desemprego. No início dos anos de 1990, sob a ameaça de fortes demissões e coerente com a idéia da livre negociação, o SMSP foi pioneiro na negociação em acordo coletivo, e à revelia da legislação, de medidas que flexibilizavam as jornadas, os salários, e os vínculos empregatícios. Essas medidas iriam posteriormente inspirar o pacote de flexibilização da CLT no segundo governo FHC. Nessa mesma linha de atuação, a Força Sindical apoiou de forma ostensiva o Projeto de Lei 5.843/01, de autoria do Executivo, para alteração da CLT e cujo teor instituía a prevalência do negociado sobre o legislado. Para uma análise instigante do discurso político e ideológico que fundamenta o pragmatismo dessa prática sindical, ver Cardoso (1999a); sobre o apoio da Força Sindical aos projetos de reformas neoliberais, tanto na militância como na negociação direta com o capital e nas trocas políticas com o Estado, ver Trópia (2003) e Gianotti (2002).

18 Para um balanço do que vem sendo negociado no plano das convenções e dos acordos coletivos de trabalho nos principais setores da economia brasileira, ver Dieese (1999 e 1999a).

19 A unicidade, a eliminação das contribuições compulsórias e o fim do poder normativo da Justiça do Trabalho estiveram no centro do debate sobre uma possível reforma na estrutura sindical desde o mo- vimento do novo sindicalismo. Não cabe aqui uma discussão mais elaborada das polêmicas que acompanham esse debate (ver, por exemplo, Boito Jr., 1991; Cardoso, 1999). Ainda que o modelo tenha perdido alguns dos seus traços corporativos, como o fim da tutela estatal e a redução do poder normativo da JT, a partir da valorização das negociações coletivas, vale observar que a idéia de pluralismo incute um paradoxo, perverso para os trabalhadores, a saber, ele divide, trabalha contra o único meio de luta possível para o lado mais fraco das relações de trabalho, a união. Como argumentou Offe (1991), se as estratégias e as possibilidades de barganha para os trabalhadores são estruturalmente mais desfavoráveis que as dos capitalistas, fomentar a concorrência no seu campo, reduzindo as possibilidades de formação de coalisões, implica enfraquecê-las ainda mais. Na mesma linha, Sady (2004, p. 4) defende: "os sindicatos não precisam de liberdade (para competir entre eles), precisam de poder". Para uma discussão calorosa sobre a questão do sindicato único versus pluralismo no Brasil, ver Moraes Filho (1978).

20 A flexibilização do $13^{\circ}$, do direito de férias e do adicional noturno estaria entre as primeiras iniciativas de negociação, como já de fato acontece para muitos trabalhadores; e não vale o argumento de que direitos garantidos na Constituição não seriam afetados: a Lei Maior, por exemplo, estabelece o direito de férias, mas não define sua duração, estabelece que a remuneração de trabalho noturno deve ser superior ao diurno, mas não define sua proporção.

21 Imaginemos os trabalhadores das indústrias tradicionais, os trabalhadores terceirizados nos mais diversos ramos da indústria e da prestação de serviços; os que trabalham no comércio, na construção civil, nos serviços de restaurante e hotelaria, isto para citar categorias de trabalhadores urbanos cobertos por relações formais de trabalho.

\section{BIBLIOGRAFIA}

ALMEIDA, M. Hermínia Tavares de. (1988), "Difícil caminho: sindicatos e política na construção da democracia”, in G. O'Donnell e F. W. Reis (orgs.), A democracia no Brasil, dilemas e perspectivas, São Paulo, Vértice.

ANTUNES, Ricardo. (2000), Os sentidos do traba- 
Iho: ensaio sobre a afirmação e a negação do trabalho. São Paulo, Boitempo.

ARAUJO, Ângela. (1998), A construção do consentimento: corporativismo e trabalhadores nos anos 30. São Paulo, Scritta.

BOITO Jr., Armando et al. (1991), O sindicalismo brasileiro nos anos 80 . Rio de Janeiro, Paz e Terra.

BOYER, Robert. (1995), "Capital-labour relations in OCDE countries: from the fordist golden age to contrasted nacional trajectories", in Capital, the State and labour: a global perspective, Londres, United Nations University Press.

CACCIAMALLI. (2000), "Globalização e processo de informalidade". Economia e Sociedade, 14: 153-174, jun.

CARDOSO, Adalberto Moreira. (1999), Sindicatos, trabalhadores e a coqueluche neoliberal: a era Vargas acabou? Rio de Janeiro, Editora da Fundação Getúlio Vargas.

(1999a), A trama da modernidade: pragmatismo sindical e democracia no Brasil. Rio de Janeiro, Iuperj/UCAM.

CARVALHO NETO, Antônio. (2001), Relações de trabalbo e negociação coletiva na virada do milênio. Petrópolis, Vozes.

CASTRO GOMES, Angela M. de. (1979), Burguesia e trabalho: política e legislação social no Brasil, 1917-1937. Rio de Janeiro, Campus.

. (2005), A invenção do trabalhismo. $3^{a}$ ed. Rio de Janeiro, Editora da FGV.

CASTRO, Nadya. (1995), "Modernização e trabalho no complexo automotivo brasileiro", in N. Castro (org.), A máquina e o equilibrista, São Paulo, Paz e Terra.

(1997), "Reestruturação produtiva, novas institucionalidades e negociação da flexibilidade". São Paulo em Perspectiva, 11 (1), jan.-mar.

CASTRO, Nadya, COMIN, Alvaro Augusto \& LEITE, Márcia de Paula. (1999), "Por um jogo de soma positiva: conciliando competitividade e proteção ao emprego em experiências inovadoras de negociação no Brasil". São Paulo, Cebrap.

COMIN, Álvaro Augusto. (1994), "A experiência de organização das centrais sindicais no Brasil", in Mattoso et al., o mundo do trabalho: crise e mudança no final do século, São Paulo, Scritta.

COMIN, Álvaro Augusto \& CASTRO, Nadya Araujo. (1998), "As novas esferas da regulação do trabalho e o dilema sindical". São Paulo em Perspectiva, 12 (1), jan.mar.

COSTA, Márcia da Silva. (2000), "Mercado ou sociedade: pode haver uma síntese?". Revista Internacional de Estudos Políticos, 2 (1): 91-114.

. (2002), Despotismo de mercado: medo do desemprego e relações de trabalho em contexto de reestruturação produtiva brasileira dos anos 90. Tese de doutorado, Rio de Janeiro, Iuperj.

DEDECCA, Claudio Salvadori. (1996), "Racionalização econômica e heterogeneidade nas relações e nos mercados de trabatho no capitalismo avançado", in Crise e trabalbo no Brasil, São Paulo, Scritta.

DIEESE. (1999), "O comportamento das negociações coletivas de trabalho nos anos 90 1993- 1996", Boletim, n. 15.

. (1999a), "Balanço das negociações salariais em 1998". Boletim DIEESE - Estudos e Pesquisa.

DINIZ, Eli. (1994), "Reformas econômicas e democracia no Brasil nos anos 90: as câmaras setoriais como fórum de negociação". Dados, 37 (2): 277-315.

DOMBOIS, Rainer \& PRIES, Ludger. (2000), Relaciones laborales entre mercado y estado: sendas de transformación en América Latina. Venezuela, Nueva Sociedad.

FNT. (2004), "Relatório final da Comissão de Sis- 
tematização". Disponível em www.mte.gov.br.

GIANNOTTI, Vito. (2002), Força sindical, a central neoliberal: de Medeiros a Paulinho. Rio de Janeiro, Mauad.

HARVEY, D. (1994), Condição pós-moderna. São Paulo, Loyola.

HUMPHREY, John. (1982), Fazendo o "milagre": controle capitalista e luta operária na indústria automobilística brasileira. Petrópolis, Vozes.

KECK, Margaret. (1988), "O novo sindicalismo na transição brasileira", in A. Stepan, Democratizando o Brasil, Rio de Janeiro, Paz e Terra.

KREIN, J. Dari. (1999), "Reforma no sistema de relações de trabalho no Brasil", in Emprego e desenvolvimento tecnológico, São Paulo, Dieese/Cesit/Unicamp.

LEITE LOPES, José Sergio. (1988), A tecelagem dos conflitos de classe na cidade das chaminés: São Paulo. Brasília, Editora da Universidade de Brasília.

LEITE, Márcia de Paula. (1992), "A crise operária e a questão sindical", in M. T. Fleury e R. M. Fischer, Processo e relações de trabalho no Brasil, São Paulo, Atlas.

MANGABEIRA, Wilma. (1993), Os dilemas do novo sindicalismo: democracia e politica em Volta Redonda. Rio de Janeiro, Relume Dumará.

MATTOSO, Jorge. (1996), A desordem do trabalho. São Paulo, Scritta.

(1999), O Brasil desempregado. São Paulo, Editora Perseu Abramo.

MEDEIROS, Carlos Aguiar. (1994), "Contrato coletivo e mercado de trabalho no Brasil", in J. Mattoso et al., O mundo do trabalbo: crise e mudança no final do século, São Paulo, Scritta.

MEDEIROS, Carlos Aguiar \& SALM, Claudio.
(1994), "O mercado de trabalho em debate". Novos Estudos Cebrap, 39, jul.

MORAES FILHO, Evaristo de. (1978), O problema do sindicato único no Brasil. São Paulo, Alfa-Omega.

NORONHA, Eduardo. (1991), "A explosão das greves na década de 80", in Boito Jr. (org.), $O$ sindicalismo brasileiro nos anos 80, São Paulo, Paz e Terra.

(1998), O modelo legislado de relações de trabalho e seus espaços normativos. Tese de doutorado, São Paulo, Universidade de São Paulo.

O'DONNELL, Guillermo. (1988), "Hiatos, instituições e perspectivas democráticas", in F. W. Reis e G. O'Donell (orgs.), A democracia no Brasil: dilemas e perspectivas, São Paulo, Vértice.

OFFE, Clauss. (1991), Capitalismo desorganizado. São Paulo, Brasiliense.

OLIVEIRA, Carlos A. Barbosa de. (1994), "Contrato coletivo e relações de trabalho no Brasil", in J. Mattoso et al., O mundo do trabalbo: crise e mudança no final do século, São Paulo, Scritta.

OLIVEIRA, Francisco. (1977), A economia brasileira: crítica à razão dualista. São Paulo, Cebrap.

PASTORE, José. (1994), Flexibilização dos mercados de trabalho e contrataçâo coletiva. São Paulo, LTr Editora.

POCHMANN, Márcio; BARRETO, Reginaldo Muniz \& MENDONÇA, Eduardo. (1998), "Ação sindical no Brasil: transformações e perspectivas". São Paulo em Perspectiva, 12 (1), jan.- mar.

RODRIGUES, Iram Jácome. (1999), "A trajetória do novo sindicalismo", in I. J. Rodrigues (org.), O novo sindicalismo vinte anos depois. Petrópolis, Vozes.

RODRIGUES, Iram Jácome \& RAMALHO, José Ricardo. (1998), "Sindicalismo na Inglaterra e no Brasil: estratégias diante das no- 
vas formas de gestão da produção". São Paulo em Perspectiva, 12 (1), jan.-mar.

RODRIGUES, J. Albertino. (1968), Sindicalismo e desenvolvimento no Brasil. São Paulo. Difusão Européia do Livro.

RODRIGUES, Leôncio Martins. (1970), Industrialização e atitudes operárias. São Paulo, Brasiliense.

. (1974), Trabalhadores, sindicato e industrialização. São Paulo, Brasiliense.

. (1991), "As tendências políticas na formação das centrais sindicais", in Boito Jr. (org.), O sindicalismo brasileiro nos anos 80, São Paulo, Paz e Terra.

SABADINI, Maurício S. \& NAKATANI, Paulo. (2002), "Desestruturação e informalidade do mercado de trabalho no Brasil". Revista Venezolana de Conyuntura, 2. jul-dez. (disponível em www.revele.com.ve/pdf/ coyuntura/volviii-n2/pag265.pdf).

SADER, Eder. (1988), Quando novos personagens entram em cena: experiências e lutas dos trabalhadores da grande São Paulo - 1970-1980. São Paulo, Paz e Terra.

SADY, João José. (2004), "Reforma sindical: o que a PEC no 29/2003 pretende é a manutenção do princípio da unicidade". Disponível em www1.jus.com.br/doutrina/texto.

SANTANA, Marco Aurélio. (1999), "Política e história em disputa: o novo sindicalismo e a idéia da ruptura com o passado", in Iram J. Rodrigues (org.), O novo sindicalismo vinte anos depois. Petrópolis, Vozes.

SANTOS, Vanderlei Guilherme dos. (1979), Cidadania e justiça: a política social na ordem brasielira. Rio de Janeiro, Campus.

SCHMITTER, Philippe. (1974), "Still the century of corporatism?", in Pike \& Strich (eds.), The new corporatism, Notre Dame, University of Notre Dame Press.

SABADINI, Maurício S. \& NAKATANI, Paulo. (2002), "Desestruturação e informalida- de do mercado de trabalho no Brasil". Revista Venezolana de Conyuntura, 2, jul.-dez. (disponível em www.revele.com.ve/pdf/coyuntura/volviiin2/pag265.pdf).

SADY, João José. (2004), "Reforma sindical: o que a PEC no 29/2003 pretende é a manutenção do princípio da unicidade". Disponível em www1.jus.com.br/doutrina/texto.

SIMÃO, Azis. (1966), Sindicato e Estado. São Paulo, Dominus.

SIQUEIRA NETO. (1996), "Flexibilização, desregulamentação e o direito do trabalho no Brasil", in C. Oliveira e J. Mattoso, Crise e trabalho no Brasil, São Paulo, Scritta.

SOUZA, D.; SANTANA, M. A. \& DELUIZ, N. (1999), Trabalbo e educação: centrais sindicais e reestruturação produtiva no Brasil. Rio de Janeiro, Quartet.

STEPAN, Alfred. (1980), Estado, corporativismo e autoritarismo. São Paulo, Paz e Terra.

TRÓPIA, Patrícia. (2003), "A adesão da Força Sindical ao neoliberalismo". Trabalho apresentado no GT "Trabalhadores, sindicatos e a nova questão social", Anpocs. Disponível em www.sindicalismo.pessoal.bridge.com.br.

VIANNA, L. Werneck. (1999), Liberalismo e sindicato no Brasil. $2^{\text {a }}$ ed. Belo Horizonte, Editora da UFMG.

WEFFORT, Francisco C. (1973), "Origens do sindicalismo populista no Brasil: a conjuntura do pós-guerra”. Estudos CEBRAP, 4, abr.-maio-jun. 


\section{O SISTEMA DE RELAÇÕES DE TRABALHO NO BRASIL: ALGUNS TRAÇOS HISTÓRICOS E SUA PRECARIZAÇÃO ATUAL}

Márcia da Silva Costa

\section{Palavras-chave}

Relações de trabalho; Sindicalismo; Desregulamentação; Perda de direitos.

Os anos de 1990 marcaram transformações profundas na economia brasileira. Os novos padrões tecnológicos e competitivos do comércio global tomaram em cheio empresas protegidas por reserva de mercado e o movimento sindical, forçando modificações nas estratégias empresariais, na gestão do trabalho, nas relações de representação, no perfil do mercado de trabalho e na legislação trabalhista. Por meio de um breve levantamento bibliográfico, procuro neste texto caracterizar as bases históricas, institucionais e políticas do sistema de relações de trabalho no país. Faço isto tentando construir uma base analítica para compreender o impacto das transformações correntes na correlação de forças que imprime mudanças àquelas relações de trabalho e sua legislação. Tais mudanças afetaram negativamente os nossos parcos direitos sociais e trabalhistas, ampliando as já arraigadas formas de trabalho flexível e precário.

\section{THE SYSTEM OF WORK RELATIONS IN BRAZIL: SOME HISTORICAL TRACES AND ITS CURRENTS PRECARIOUNESS}

Márcia da Silva Costa

\section{Keywords}

Work relationships; Syndicalism; Deregulation; Loss of rights.

The nineties marked deep transformations in the Brazilian economy. The new technological and competitive patterns of the global trade have shaken companies and union movements forcing changes in managerial strategies, work administration, representation relationships, job market, and labor legislation. From a short bibliographic survey this paper intends to characterize the historical, institutional, and political bases of the Brazilian work relations system. I do this trying to build an analytical reference to understand the impact of the current transformations in the correlation of forces that impose changes to those work relations and its legislation. Such changes affected our weak social and work rights negatively increasing the already rooted forms of precarious and flexible work.

\section{LE SYSTÈME DES RAPPORTS DE TRAVAIL AU BRÉSIL: QUELQUES ASPECTS HISTO- RIQUES ET PRÉCARITÉ AC- TUELLE}

Márcia da Silva Costa

\section{Mots-clés}

Rapports de travail; Syndicalisme; Déréglementation. Perte de droits.

Les années 1990 ont été marquées par des transformations profondes dans l'économie brésilienne. Les nouveaux paradigmes technologiques et compétitifs du commerce global ont atteint de plein fouet les entreprises protégées par des réserves de marché et par le mouvement syndical, ce qui a forcé des modifications dans les stratégies des entreprises par rapport à la gestion du travail, les relations de représentation, le profil du marché du travail et les lois travaillistes. Grâce à une brève bibliographie, nous avons cherché, dans ce texte, à caractériser les bases historiques, institutionnelles et politiques du système des rapports de travail au Brésil. Cela a été fait pour tenter de construire une base analytique permettant de comprendre l'impact des transformations courantes dans la corrélation de forces qui impriment des changements dans les rapports de travail et les lois du travail. De tels changements ont affecté de façon négative nos pauvres droits sociaux et du travail, en élargissant les formes établies de travail flexible et précaire. 